\title{
Second Malignant Neoplasms in Children and Adolescents Treated for Blood Malignancies and Solid Tumors: A Single-Center Experience of 15 Years
}

\begin{abstract}
Context: The occurrence of second malignancies is not rare in children treated for primary tumors Objectives: The aim of this study was to investigate the occurrence and the outcomes of second malignancies in children and adolescents from a large tertiary pediatric hematology-oncology center. Materials and Methods: A retrospective study was performed looking into the characteristics and outcomes of second malignant neoplasms in children and adolescents treated for primary malignancies in a single center over a 15-year period. Results: Among 270 children and adolescents treated for hematological malignancies and solid tumors from 2000 to 2015, five cases of second malignancy were diagnosed including cancer of the parotid gland, renal cell carcinoma, Hodgkin's lymphoma, thyroid carcinoma, and transitional liver cell carcinoma in patients previously treated for acute myeloid leukemia, glioblastoma multiforme, B-acute lymphoblastic leukemia, Langerhans cell histiocytosis, and medulloblastoma, respectively. Primary malignancies were treated with chemotherapy in all cases and four out of five patients had also received radiotherapy. Mean age at diagnosis of second malignancy was 10 years and 4 months. Overall survival after diagnosis of second malignancy was $80 \%$ at 12 months and $75 \%$ at 5 years. Conclusions: Close surveillance and long-term follow-up are mandatory for the identification of late effects in children treated for malignancy.
\end{abstract}

Keywords: Childhood cancer, late effects, second malignant neoplasm

\section{Introduction}

The development of effective therapies for childhood cancer has led to an increased incidence of long-term toxicity. Second malignant neoplasm (SMN) is a leading cause of morbidity and mortality among cancer survivors. The 5-year relative survival rate of childhood cancer exceeds $80 \%{ }^{[1,2]}$ It is estimated that $5 \%-10 \%$ of children who have been treated for primary malignancy will develop an SMN with a 20-year cumulative incidence of SMN in childhood survivors of $3.2 \%{ }^{[3-12]}$ Risk factors for the occurrence of SMN include patient- and therapy-related characteristics, including young age at primary diagnosis, female gender, use of chemotherapy, radiation therapy, and genetic factors. ${ }^{[1-9]}$

Primary neoplasms that are more commonly associated with SMN include leukemia, lymphoma, retinoblastoma, medulloblastoma, craniopharyngioma, and neuroblastoma. ${ }^{[13-16]}$ Radiation therapy is

This is an open access journal, and articles are distributed under the terms of the Creative Commons Attribution-NonCommercial-ShareAlike 4.0 License, which allows others to remix, tweak, and build upon the work non-commercially, as long as appropriate credit is given and the new creations are licensed under the identical terms.

For reprints contact: reprints@medknow.com used therapeutically or preemptively in pediatric malignancies and has been linked with increased survival rates not without late effects. The term radiation-induced malignancy is used to describe malignancies which occur in tissues exposed to radiation that arise from the primary malignancy. ${ }^{[17-20]}$ The more common SMNs are acute myeloid leukemia (AML), myelodysplastic syndrome, thyroid carcinoma, and central nervous system (CNS) tumors.

Adult-type malignancies occur rarely in children. Chemotherapy, radiation therapy, and genetic predisposition are known risk factors for the occurrence of adult-type tumors in childhood. Sarcomas are the most common adult-type tumors and can affect organs that are distant from primary tumors. The aim of this study was to investigate the occurrence and the outcomes of SMN from a large tertiary pediatric hematology-oncology center.

\footnotetext{
How to cite this article: Katzilakis $\mathrm{N}$, Tsirigotaki M, Stratigaki M, Kampouraki E, Athanasopoulos E, Markaki EA, et al. Second malignant neoplasms in children and adolescents treated for blood malignancies and solid tumors: A single-center experience of 15 years. Indian J Med Paediatr Oncol 2018;39:483-7.
}

\section{Nikolaos Katzilakis, Maria Tsirigotaki, Maria Stratigaki, Eleni Kampouraki, Emmanouil Athanasopoulos, Erasmia Athina Markaki, Antonis Kattamis ${ }^{1}$, Eftichia Stiakaki}

Department of Pediatric Hematology-Oncology, University Hospital of Heraklion, University of Crete, Heraklion, ' Division of Pediatric Hematology-Oncology, Department of Pediatrics, University of Athens, Aghia Sofia Children's Hospital, Athens, Greece
Address for correspondence: Dr. Eftichia Stiakaki, Department of Pediatric Hematology-Oncology, University of Crete, Voutes, 71003, Heraklion, Greece. E-mail: efstel@med.uoc.gr

Access this article online Website: www.ijmpo.org DOI: 10.4103/ijmpo.ijmpo_102_17 Quick Response Code:

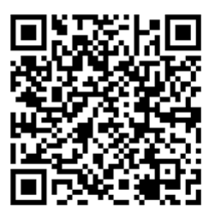




\section{Materials and Methods}

We performed a retrospective, observational study of SMNs in children aged 1 month to 18 years who were diagnosed and treated for primary hematological malignancies and solid tumors in a tertiary Pediatric Hematology Oncology Department between January 2000 and December 2015. A total of 270 medical records were analyzed, SMN cases were identified, and parameters that were analyzed included primary diagnosis, age at diagnosis of primary and second malignancy, sex, type of treatment received (chemotherapy, radiotherapy), family history of malignancy, genetic mutations when available and outcomes after SMNs.

\section{Results}

A total of 270 medical records were reviewed from children aged 1 month to 18 years that were diagnosed and treated for primary hematological malignancies and solid tumors from 2000 till 2015 with a follow-up time of 6 months to 15 years. Medical records were also available after transition to adult services, with none lost to follow up. Over a 15-year period, five patients - 5 boys, 0 girls - were diagnosed with second malignancies. SMNs included cancer of the parotid gland, renal cell carcinoma, Hodgkin's lymphoma, thyroid carcinoma, and transitional liver cell carcinoma in patients previously diagnosed and treated for AML, glioblastoma multiforme, B-acute lymphoblastic leukemia (B-ALL), Langerhans cell histiocytosis (LCH), and medulloblastoma, respectively. Patients' characteristics and associations between primary and secondary malignancies are displayed in Table 1.

Mean age at primary diagnosis was 5 years and 4 months (range: 2 years and 9 months to 8 years and 7 months). Mean age at diagnosis of second malignancy was 10 years and 4 months (range: 7 years and
10 months to 14 years and 4 months). All patients had received chemotherapy for their primary diagnosis and $80 \%(4 / 5)$ had also received radiation therapy. Median time from primary diagnosis to second malignancy was 5 years (range: $3-10$ years). Among patients who received radiotherapy and developed second malignancy, $50 \%$ of SMN occurred at the site of previous radiation exposure.

\section{Case 1}

A 14-year-old male child presented with painless parotid mass 10 years after successful treatment of AML according to the AML-BFM-1998 protocol with chemotherapy and cranial radiotherapy (18 Gy). Complete excision of the parotid gland was performed with histological diagnosis of low-grade mucoepidermoid carcinoma. His 5-year follow-up has been uneventful.

\section{Case 2}

A previously well 3-year-old male child was diagnosed with high-grade glioma Grade IV according to the WHO classification, glioblastoma multiforme. Surgical excision of the lesion was performed and he received cranial radiotherapy (54 Gy) and temozolomide (200 mg/m²/24 h) for 5 months. He developed two relapses 6 months and 1 year after primary excision, which were managed by surgery, placement of ventriculoperitoneal shunt and further chemotherapy. At the age of 8 years, while he had been disease free for $>4$ years, he presented with a left-sided renal mass which was histologically consistent with renal cell carcinoma, stage T3A (TNM/AJCC staging system). Genetic analysis revealed a de novo mutation of $\mathrm{p} 53$ gene (G245S) [Figure 1a].

\section{Case 3}

Diagnosed with B-ALL at the age of 5.5 years and treated according to ALL-BFM 2000 High-Risk Protocol with chemotherapy and cranial radiotherapy (12 Gy), a

\begin{tabular}{|c|c|c|c|c|c|c|c|c|}
\hline Case & Sex & $\begin{array}{l}\text { Primary } \\
\text { Diagnosis }\end{array}$ & $\begin{array}{l}\text { Age at } \\
\text { Primary } \\
\text { Diagnosis }\end{array}$ & Treatment & $\begin{array}{l}\text { Second } \\
\text { Malignancy }\end{array}$ & $\begin{array}{c}\text { Age at } \\
\text { Second } \\
\text { Malignancy }\end{array}$ & $\begin{array}{l}\text { Family } \\
\text { History }\end{array}$ & Follow-up \\
\hline 1 & M & AML & $4 \mathrm{yr} 1 \mathrm{mo}$ & $\begin{array}{l}\text { Chemo, } \\
\text { RT }\end{array}$ & Ca parotid & $14 \mathrm{yr} 4 \mathrm{mo}$ & Neg & 5 year \\
\hline 2 & M & Glioblastoma multiforme & $2 \mathrm{yr} 9 \mathrm{mo}$ & $\begin{array}{l}\text { Chemo, } \\
\text { Surgery, } \\
\text { RT }\end{array}$ & $\begin{array}{l}\text { Renal cell } \\
\text { carcinoma }\end{array}$ & $8 \mathrm{yr} 10 \mathrm{mo}$ & $\mathrm{Neg}$ & 2 year \\
\hline 3 & M & B-ALL & 5 yr 5 mo & Chemo, RT & $\begin{array}{l}\text { Hodgkin } \\
\text { Lymphoma }\end{array}$ & $10 \mathrm{yr} 1 \mathrm{mo}$ & Neg & 6 year \\
\hline 4 & M & $\mathrm{LCH}$ & 5 yr 9 mo & $\begin{array}{l}\text { Chemo, } \\
\text { Surgery }\end{array}$ & $\begin{array}{l}\text { Thyroid } \\
\text { carcinoma }\end{array}$ & $7 \mathrm{yr} 10 \mathrm{mo}$ & Neg & 5 year \\
\hline 5 & M & Medulloblastoma & $8 \mathrm{yr} 7 \mathrm{mo}$ & $\begin{array}{l}\text { Chemo, } \\
\text { Surgery, } \\
\text { RT }\end{array}$ & $\begin{array}{l}\text { Transitional } \\
\text { liver cell } \\
\text { tumor }\end{array}$ & $10 \mathrm{yr} 9 \mathrm{mo}$ & Pos & 2 mo (died) \\
\hline
\end{tabular}

AML - Acute myelogenous leukemia; B-ALL - B-acute lymphoblastic leukemia; Chemo - Chemotherapy; RT - Radiation therapy; Neg - Negative; Pos - Positive 
10-year old male child presented with supraclavicular lymphadenopathy and splenomegaly. Lymph node biopsy revealed nodular sclerosis, Hodgkin's lymphoma, Stage IIIB [Figure 1b]. He received chemotherapy with doxorubicin, bleomycin, vincristine, etoposide, cyclophosphamide, and prednisolone according to the COG AHOD0031 protocol and has remained disease free in a 5-year follow-up.

\section{Case 4}

A 5-year-old male child was diagnosed with LCH of the right femur and was managed with surgical resection, vinblastine, and prednisolone according to $\mathrm{LCH}$ III protocol. Two years after the completion of chemotherapy, he was diagnosed with papillary thyroid carcinoma with cervical lymph node metastases. There was no relevant family history and no radiation exposure. After thyroidectomy and radioiodine therapy, he has remained asymptomatic in a 5-year follow-up.

\section{Case 5}

An 8-year-old male child with positive family of malignancy (father with Hodgkin's disease, mother with breast cancer) was diagnosed with Grade 4 medulloblastoma of the cerebellum with leptomeningeal spread which was managed with surgical excision and treated as per high-risk medulloblastoma SIOP protocol with methotrexate, vincristine, etoposide, cyclophosphamide, carboplatin, lomustine, and cranial irradiation (54 Gy). Twenty-six months after his primary diagnosis, he was diagnosed with transitional liver cell tumor (TLCL) [Figure 1c]. He was treated with chemotherapy and surgical excision but developed multi-organ failure and passed away 2 months later. Genetic testing was not available in his case due to lack of parental consent.

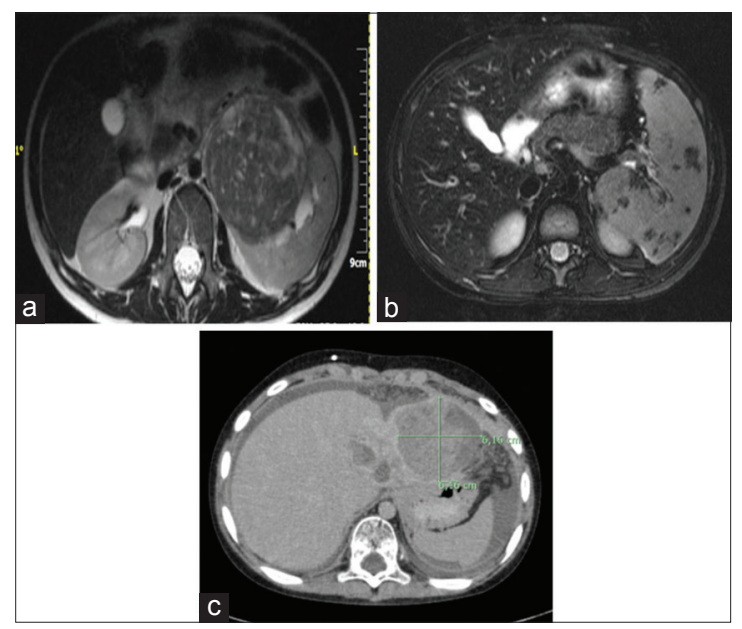

Figure 1: (a-c) Abdominal magnetic resonance image of Case 2, Case 3, and Case $\mathbf{5}$ showing left-sided renal cell carcinoma, stage IIIB Hodgkin's lymphoma, and transitional liver cell tumor, respectively

\section{Outcome}

Second malignancies were managed with chemotherapy $(2 / 5)$, surgical excision (4/5) and in one case (case 3) required splenectomy. Overall survival was $80 \%(4 / 5)$ at 12 months and $75 \%(3 / 4)$ at 5 years.

\section{Discussion}

Increased survival of children treated for primary malignancies has led to an increased risk of late effects, among which SMNs are the most serious. It is estimated that $5 \%-10 \%$ of all children treated for primary malignancy will develop SMN. ${ }^{[4-6]}$ For childhood cancer survivors, the 20-year cumulative incidence has been estimated at $3.2 \% \cdot{ }^{[1-12]}$ Acute lymphoblastic leukemia (ALL), Hodgkin's disease, and retinoblastoma are the primary malignancies more commonly associated with the occurrence of SMNs. ${ }^{[1,5,21]}$ ALL is the most common malignancy in childhood. The estimated cumulative incidence of second malignancy in patients who have received treatment for ALL is $2.5 \%$ at 15 years after primary diagnosis and radiation is a known risk factor for SMN. ${ }^{[9,19]}$ Known risk factors for the occurrence of second malignancy in this group are age $<5$ years, female gender, cranial radiation, and disease relapse, and the most common second malignancies include CNS tumors and hematological malignancies. ${ }^{[1,8]}$ In our institution, among 75 ALL survivors, SMN was observed in one case, 10 years after primary diagnosis.

AML is four times less common than ALL in childhood with an estimated survival rate of $>65 \% .^{[22-24]}$ In previous studies, AML survivors have been shown to have a 10 -fold increased risk of malignancy compared to the general population. ${ }^{9]}$ In this study, we describe a case of parotid cancer in a child treated for AML with chemotherapy and irradiation $>10$ years after his primary diagnosis. Mucoepidermoid carcinoma of the parotid is a rare malignancy in children. As SMN, it has been previously described in patients treated for ALL and rarely in children treated for AML. ${ }^{[9,25,26]}$

Few reports have been published regarding SMNs in patients treated for glioblastoma. ${ }^{[27,28]}$ We describe here a rare case of an 8-year male child who presented with renal cell carcinoma 6 years after his treatment for glioblastoma. Renal cell carcinoma is the most common renal malignancy in adults, but it is rare in childhood. It has been described as second malignancy in patients treated for Wilms' tumor and neuroblastoma survivors. ${ }^{[29,30]}$ Childhood cancer survivors have an 8-fold risk of developing renal cell carcinoma compared with the general population. ${ }^{[31]}$ To our knowledge, this is an uncommon case of renal cell carcinoma occurring in patient treated for glioblastoma.

Mutations of the tumor suppressor gene p53 have been associated with many types of human cancer. Apart from sporadic mutations, p53 mutations can arise as part of cancer predisposition syndromes and close surveillance 
is required in known mutation carriers to identify asymptomatic neoplasms. Association of p53 and renal cell carcinoma is well known in adults. ${ }^{[32]}$

Association of LCH and papillary thyroid carcinoma has been previously reported and is more common in adults than children. ${ }^{[33-36]}$ We describe here a rare case of metachronous papillary thyroid carcinoma in an 8-year-old child who presented 2 years after the completion of International LCH III treatment protocol with prednisolone and vinblastine. As the thyroid gland can be involved directly or indirectly in patients with $\mathrm{LCH}$, it is important to highlight the need for close follow-up of these patients and examination of the thyroid gland.

Medulloblastoma is the most common malignant CNS tumor in children. It is estimated that patients treated for medulloblastoma have a $2 \%-7 \%$ cumulative 10 -year incidence rate of second malignancy. ${ }^{[35-39]}$ It has been previously shown that second non-CNS malignancy is more likely to occur at the site of primary radiation. ${ }^{[40]}$ Here, we present a case of TLCL after treated of medulloblastoma with chemotherapy and radiotherapy. TLCL is a rare, rapid-growing malignancy with very poor prognosis. Only few cases of TLCL have been reported in literature and even fewer have been described as SMN. ${ }^{[41]}$

The occurrence of adult-type second malignancies is not common in childhood. We describe here two cases of adult type malignancies - one case of renal cell carcinoma and one of TLCL that occurred 6 and 3 years after diagnosis of primary diagnosis, respectively, at sites distant from primary malignancy. This highlights the need for careful systemic follow-up of children who have survived primary malignancies.

Mortality is higher in childhood cancer survivors compared with the general population and occurrence of SMN account for a significant proportion of non-relapse-related mortality. In this study, SMN-related mortality was $20 \%(1 / 5)$ in a 15 -year study period. Adult-type malignancies have an increased risk of mortality when occurring in childhood. In this 15-year study period, mortality caused by adult-type second tumors was $50 \%$.

In our study, mean age at diagnosis of second malignancy was 10 years and 4 months (range: 7 years and 10 months to 14 years and 4 months). Mean time from diagnosis of primary to second malignancy was 5 years (range: 2 years 1 month to 10 years 3 months), compared with 2-8 years published elsewhere. ${ }^{[13-18,27-29,42]}$ These results support the need for close, long-term follow-up of pediatric cancer survivors for late effects.

\section{Conclusion}

The occurrence of SMNs in children and adolescents who have received treatment for primary tumors is not rare. An increased risk of developing subsequent malignant neoplasms implies the need of close surveillance and long-term follow-up.

\section{Financial support and sponsorship}

Nil.

\section{Conflicts of interest}

There are no conflicts of interest.

\section{References}

1. Ng AK, Kenney LB, Gilbert ES, Travis LB. Secondary malignancies across the age spectrum. Semin Radiat Oncol 2010;20:67-78.

2. Morton LM, Onel K, Curtis RE, Hungate EA, Armstrong GT. The rising incidence of second cancers: Patterns of occurrence and identification of risk factors for children and adults. Am Soc Clin Oncol Educ Book 2014:e57-67.

3. Garaventa A, Gambini C, Villavecchia G, Di Cataldo A, Bertolazzi L, Pizzitola MR, et al. Second malignancies in children with neuroblastoma after combined treatment with 131I metaiodobenzylguanidine. Cancer 2003;97:1332-8.

4. Duffner PK, Krischer JP, Horowitz ME, Cohen ME, Burger PC, Friedman HS, et al. Second malignancies in young children with primary brain tumors following treatment with prolonged postoperative chemotherapy and delayed irradiation: A Pediatric Oncology Group study. Ann Neurol 1998;44:313-6.

5. Vázquez E, Castellote A, Piqueras J, Ortuno P, Sánchez Toledo J, Nogués P, et al. Second malignancies in pediatric patients: Imaging findings and differential diagnosis. Radiographics 2003;23:1155-72.

6. Moppett J, Oakhill A, Duncan AW. Second malignancies in children: The usual suspects? Eur J Radiol 2001;37:95-108.

7. Norkin M, Uberti JP, Schiffer CA. Very late recurrences of leukemia: Why does leukemia awake after many years of dormancy? Leuk Res 2011;35:139-44.

8. Maule M, Scélo G, Pastore G, Brennan P, Hemminki K, Tracey E, et al. Risk of second malignant neoplasms after childhood leukemia and lymphoma: An international study. J Natl Cancer Inst 2007;99:790-800.

9. Leung W, Ribeiro RC, Hudson M, Tong X, Srivastava DK, Rubnitz JE, et al. Second malignancy after treatment of childhood acute myeloid leukemia. Leukemia 2001;15:41-5.

10. Landier W, Armenian S, Bhatia S. Late effects of childhood cancer and its treatment. Pediatr Clin North Am 2015;62:275-300.

11. Friedman DL, Whitton J, Leisenring W, Mertens AC, Hammond S, Stovall M, et al. Subsequent neoplasms in 5 year survivors of childhood cancer: The Childhood Cancer Survivor Study. J Natl Cancer Inst 2010;102:1083 95.

12. de Vathaire F, Scwhartz B, El Fayech C, Allodji RS, Escudier B, Hawkins M, et al. Risk of a second kidney carcinoma following childhood cancer: Role of chemotherapy and radiation dose to kidneys. J Urol 2015;194:1390-5.

13. Nakano Y, Fujimaru R, Ishii K, Sakamoto H, Inoue T, Sako M, et al. Childhood pheochromocytoma in a survivor of central primitive neuroectodermal tumor. Pediatr Int 2013;55:e100-2.

14. Caglar K, Unal S, Cetinkaya A, Gümrük F, Yetgin S. Acute lymphoblastic leukemia as a second malignant neoplasm in a child with medulloblastoma. Pediatr Hematol Oncol 2003;20:535-7.

15. Ragusa R, Russo S, Villari L, Schilirò G. Hodgkin's disease as a second malignant neoplasm in childhood: Report of a case and review of the literature. Pediatr Hematol Oncol 2001;18:407-14

16. Geetha N, SreedeviAmma N, Kusumakumary P, Lali VS, Nair MK. Acute lymphoblastic leukemia occurring as a second 
malignancy: Report of a case and review of literature. Pediatr Hematol Oncol 1999;16:267-70.

17. Cahan WG, Woodard HQ, Higinbotham NL, Stewart FW, Coley BL. Sarcoma arising in irradiated bone; report of 11 cases. Cancer 1948;1:3-29.

18. Schrantz JL, Araoz CA. Radiation induced meningeal fibrosarcoma. Arch Pathol 1972;93:26-31.

19. Zhang AY, Judson I, Benson C, Wunder JS, Ray-Coquard I, Grimer RJ, et al. Chemotherapy with radiotherapy influences time-to-development of radiation-induced sarcomas: a multicenter study. Br J Cancer 2017;25;117:326-31.

20. Kunert P, Matyja E, Prokopienko M, Marchel A. Radiation induced tumours of meninges. Report on eight cases and review of the literature. Neurol Neurochir Pol 2012;46:542-52.

21. Meadows AT, Friedman DL, Neglia JP, Mertens AC, Donaldson SS, Stovall M, et al. Second neoplasms in survivors of childhood cancer: Findings from the childhood cancer survivor study cohort. J Clin Oncol 2009;27:2356-62.

22. Rubnitz JE, Inaba H, Dahl G, Ribeiro RC, Bowman WP, Taub J, et al. Minimal residual disease directed therapy for childhood acute myeloid leukaemia: Results of the AML02 multicentre trial. Lancet Oncol 2010;11:543-52.

23. Creutzig U, Zimmermann M, Dworzak MN, Ritter J, Schellong G, Reinhardt D. Development of a curative treatment within the AML BFM studies. Klin Padiatr 2013;225 Suppl 1:S79-86.

24. Pession A, Masetti R, Rizzari C, Putti MC, Casale F, Fagioli F, et al. Results of the AIEOP AML 2002/01 multicenter prospective trial for the treatment of children with acute myeloid leukemia. Blood 2013;122:170-8.

25. Prasannan $\mathrm{L}, \mathrm{Pu} \mathrm{A}$, Hoff $\mathrm{P}$, Weatherly $\mathrm{R}$, Castle V. Parotid carcinoma as a second malignancy after treatment of childhood acute lymphoblastic leukemia. J Pediatr Hematol Oncol 1999;21:535-8.

26. Tikku G, Jain D, Kumari A, Grover R. Mucoepidermoid carcinoma of parotid as a second malignancy in acute lymphoblastic leukemia. Indian Pediatr 2015;52:979-80.

27. Koh KN, Yoo KH, Im HJ, Sung KW, Koo HH, Kim HS, et al. Characteristics and outcomes of second malignant neoplasms after childhood cancer treatment: Multi center retrospective survey. J Korean Med Sci 2016;31:1254-61.

28. Kraushaar G, Wiebe S. Renal cell carcinoma as a second malignant neoplasm in a patient with non syndromic hemihypertrophy and previous Wilms tumor. Pediatr Radiol 2005;35:1208-11.

29. Lazarus J, Moolman C. Renal cell carcinoma as second malignancy in patient with previous Wilms tumor. Urology 2009;74:598-600.

30. Neglia JP, Friedman DL, Yasui Y, Mertens AC,
Hammond S, Stovall M, et al. Second malignant neoplasms in five year survivors of childhood cancer: Childhood cancer survivor study. J Natl Cancer Inst 2001;93:618-29.

31. Villani A, Shore A, Wasserman JD, Stephens D, Kim RH, Druker $\mathrm{H}$, et al. Biochemical and imaging surveillance in germline TP53 mutation carriers with Li Fraumeni syndrome: 11 year follow up of a prospective observational study. Lancet Oncol 2016;17:1295-305.

32. Guarino S, Giusti DM, Rubini A, Favoriti P, Fioravanti C, Di Matteo FM, et al. Association between pituitary langerhans cell histiocytosis and papillary thyroid carcinoma. Clin Med Insights Case Rep 2013;6:197-200.

33. Jamaati HR, Shadmehr MB, Saidi B, Khosravi A, Arab M, Mohammadi F. Langerhans cell histiocytosis of the lung and thyroid, co existing with papillary thyroid cancer. Endocr Pathol 2009;20:133-6.

34. Patten DK, Wani Z, Tolley N. Solitary langerhans histiocytosis of the thyroid gland: A case report and literature review. Head Neck Pathol 2012;6:279-89.

35. Moschovi M, Adamaki M, Vlahopoulos S, Rodriguez Galindo C. Synchronous and metachronous thyroid cancer in relation to Langerhans cell histiocytosis; involvement of V600E BRAF mutation? Pediatr Blood Cancer 2015;62:173-4.

36. Goldstein AM, Yuen J, Tucker MA. Second cancers after medulloblastoma: Population based results from the United States and Sweden. Cancer Causes Control 1997;8:865-71.

37. Milde T, Oehme I, Korshunov A, Kopp Schneider A, Remke M, Northcott P, et al. HDAC5 and HDAC9 in medulloblastoma: Novel markers for risk stratification and role in tumor cell growth. Clin Cancer Res 2010;16:3240-52.

38. Packer RJ, Zhou T, Holmes E, Vezina G, Gajjar A. Survival and secondary tumors in children with medulloblastoma receiving radiotherapy and adjuvant chemotherapy: Results of Children's Oncology Group trial A 9961. Neuro Oncol 2013;15:97-103.

39. Nomura Y, Yasumoto S, Yanai F, Akiyoshi H, Inoue T, Nibu K, et al. Survival and late effects on development of patients with infantile brain tumor. Pediatr Int 2009;51:337-41.

40. Lau CS, Mahendraraj K, Chamberlain RS. Hepatocellular carcinoma in the pediatric population: A population based clinical outcomes study involving 257 patients from the surveillance, epidemiology, and end result (SEER) database (1973 2011). HPB Surg 2015;2015:670728.

41. Ozcan HN, Oguz B, Salim T, Talim B, Haliloglu M. A rare malignant hepatic tumor of childhood: Transitional liver cell tumor revisited. JBR-BTR 2015;98:79-81.

42. Goyal S, Singh RR, Balukrishna S, Bindra M, Backianathan S. An early and rare second malignancy in a treated glioblastoma multiforme: Is it radiation or temozolomide? J Clin Diagn Res 2015;9:TD05-7. 